\title{
Water quality issues and management of large rivers
}

\author{
H. Habersack ${ }^{1}$ R. Samek ${ }^{1}$
}

Received: 26 April 2016/Accepted: 28 April 2016/Published online: 12 May 2016

(C) Springer-Verlag Berlin Heidelberg 2016

The 2nd International Conference on the Status and Future of the World's Large Rivers (WLR) in Manaus was organized by an international scientific committee, led by the University of Natural Resources and Life Sciences, Vienna, Austria, together with a local organizing committee led by the Universidade Federal do Amazonas, Manaus, Brazil. The conference was held in Manaus, Brazil, in the immediate vicinity of the Rio Negro. The key theme in this event was the pressures and impacts on the world's large rivers that have increased greatly in recent years, as a consequence of their exploitation to meet human needs. Large rivers are particularly exposed to problems of multiple uses, often with conflicting aims. At the global scale, there is no overview assessment of the current status of the world's large rivers, the conflicting demands on such rivers, and likely future anthropogenic impacts, as well as the potential for restoration and the associated problems.

The aim of the International Conference on the Status and Future of the World's Large Rivers is to provide a global forum for a wide-ranging discussion of key issues related to research on large rivers and to their effective and sustainable management, involving both scientists and decision-makers. The first conference took place in 2011 in Vienna, Austria, and was continued in 2014 in Manaus, Brazil, with the following four main conference topics.

Due to the head location of the conference (Manaus), one main issue was Amazonia and South America. Researchers expressed the insights of the relevant research environments in 41 oral presentations. These covered various research fields such

Responsible editor: Philippe Garrigues

H. Habersack

helmut.habersack@boku.ac.at

1 Institute of Water Management, Hydrology and Hydraulic Engineering, University of Natural Resources and Life Sciences, Vienna, Vienna, Austria as measuring and modelling methods, sediment transport, floodplain and watershed management, ecosystem stability, dissolved organic and anorganic pollution or sediment transport, and water quality. These researches were implemented in South America and Amazonia covering the following rivers: Amazon (Brazil), Xingu River (Brazil), Negro River (Brazil, Colombia, and Venezuela), Paraná River (Argentina), Orinoco River (Columbia and Venezuela), and Uruguay River (Argentina, Brazil, and Uruguay).

Further key issues had river-related thematic focuses without areal context.

Within the thematic block Hydrology, Hydraulics \& Water Quality, 40 presentations covered that issue for a large number of international waterbodies.

In 45 presentations, interesting insights to the thematic field of Sediment Transport, Material Fluxes \& River Morphology were provided.

In Ecology \& Restoration, 40 presentations were held to show the latest findings within that research field.

This special issue ESPR publishes seven articles, which are based on the oral presentations at the WLR conference 2014 covering the research field of organic and anorganic river pollution, as well as water quality changes and their relevance for regions in South America, Turkey, and China.

Moquet et al. (2016) estimate in their paper the major dissolved species flux of the Amazon River from the Andes to the ocean. Based on the data of the "Programa Climatologico $y$ Hydrologico de la Cuenca Amazonica de Bolivia” (PHICAB) and the HYBAM, they show a first global observation of temporal dynamics of each geomorphological domain and fluxes. The observations highlight that the geomorphological and geological setting under tropical context is primarily controlling the weathering flux repartition.

D'Arc de Paula et al. (2016) examined the organic carbon distribution in the Amazon River basin. All project areas showed coarse particulate organic carbon as the most abundant fraction in biomass. Rainfall and soil fertility have an influence on the 
carbon distribution. These results could have an influence on the global carbon calculations for the region.

In a third paper concerning the Amazon River, the water quality for domestic use by the riverine community as well as the water quality of the river was examined by Pantoja et al. (2016). The water quality standard for Brazil was compared with the values from the households via parameters such as turbidity, color, $\mathrm{pH}$, conductivity, nitrate, nitrite, and sulfate. The results indicate an inappropriate treatment of the river water for the households, especially in the flood season.

Based on the data from October 2008 to July 2010, the relevance of hydrology on the fluvial water quality of the Paraná River (Argentina) is presented by Puig et al. (2016a). Within the study period, a drought with low flows as well as a large flood event (10 years of recurrence interval and 7 months prolonging) occurred during the project. They show that hydrologic parameters have a high influence on the water quality.

Further, the same team worked on alterations in the flow regime and fluvial pollution warnings at the Paraná River (Puig et al. 2016b). Flow characteristics were compared with Indicators of Hydrologic Alteration and Environmental Flow Components, which constitute useful tools for evaluating trends and changes of ecological and social relevance.

Yllmaz and Koç (2016) present their studies on organic pollution of the Büyük Menderes River (Turkey) and the effects on aquaculture. Between 2000 and 2013, measuring had been done at eight stations on the river. The water parameters where classified according to the "Turkish water pollution control regulation" and further compared with the TS 266 and WHO guidelines. The results show an influence on fish species.

Yang et al. (2016) focus on the water quality changes correlated to changes in land use patterns of the Three Gorges Reservoir in China. A priority was connecting nonpoint source nutrient pollutants to the main land use categories forest, upland, paddy field, and pasture over a study period of 16 years. Hereby, the increase of the water volume in the reservoir has a main influence.

This issue gives recent scientific insights into water quality issues of large rivers and was only possible with the generous contribution of the authors, the reviewers, and the journal editors who handled the submissions.

\section{References}

D’Arc de Paula J, Luizão FJ, Fernandez Piedade MT (2016) The size distribution of organic carbon in headwater streams in the Amazon basin. Environ Sci Pollut Res. doi: 10.1007/s11356-016-6041-6

Moquet JS, Guyot JL, Crave A, Viers J, Filizola N, Martinez JM, Oliveira TC, Hidalgo Sánchez LS, Lagane C, Lavado Casimiro WS, Noriega L, Pombosa R (2016) Amazon River dissolved load: temporal dynamics and annual budget from the Andes to the ocean. Environ Sci Pollut Res. doi: 10.1007/s11356-015-5503-6
Pantoja, NPG, Castro LM, Rocha SD, Silva JA, Ribeiro JSP, Donald AR, Silva LM, Oliveira TCS (2016) Quality of the Solimões River water for domestic use by the riverine community situated in Manacapuru - Amazonas - Brazil. Environ Sci Pollut Res. doi: 10.1007/s11356015-5025-2

Puig A, Olguín Salinas HF, Borús JA (2016a). Relevance of the Paraná River hydrology on the fluvial water quality of the Delta Biosphere Reserve. Environ Sci Pollut Res. doi: 10.1007/s11356-015-5744-4

Puig A, Olguín Salinas HF, Borús JA (2016b). Recent changes (19732014 versus 1903-1972) in the flow regime of the Lower Paraná River and current fluvial pollution warnings in its Delta Biosphere Reserve. Environ Sci Pollut Res. doi: 10.1007/s11356-016-6501-z

Yang H, Wang G, Wang L, Zheng B (2016) Impact of land use changes on water quality in headwaters of the Three Gorges Reservoir. Environ Sci Pollut Res. doi: 10.1007/s11356-015-5922-4

Yılmaz E, Koç C (2016) Organic pollution of the Büyük Menderes River, Turkey and the effects on aquaculture. Environ Sci Pollut Res. doi: 10.1007/s11356-016-6397-7

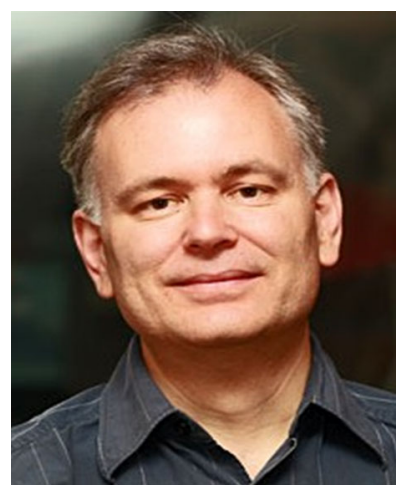

Helmut Habersack Univ.Prof. Dipl.Ing. Dr.nat.techn. Helmut Habersack habilitated in "River hydraulics and river engineering" at BOKU in 2001 and became Full Professor for Hydraulic Engineering and Modelling in 2011. Throughout his scientific work, he conducted a great number of projects - 60 finished and 24 current national and international projects. To this day, he held more than 100 national and international talks and published over 110 articles. Since May 2010, he is head of the Christian Doppler Laboratory for Advanced Methods in River Monitoring, Modelling and Engineering, and since 2011, he is head of the Institute of Water Management, Hydrology and Hydraulic Engineering. Moreover, he is the initiator and coordinator of the UNESCO World's Large Rivers Initiative and holds the UNESCOChair for Integrated River Research and Management. Additionally, he has been visiting professor at the UC Berkeley and the University of Minnesota, St. Anthony Falls Laboratory, USA, in 2009 and at the Kyoto University, Japan, in 2015.

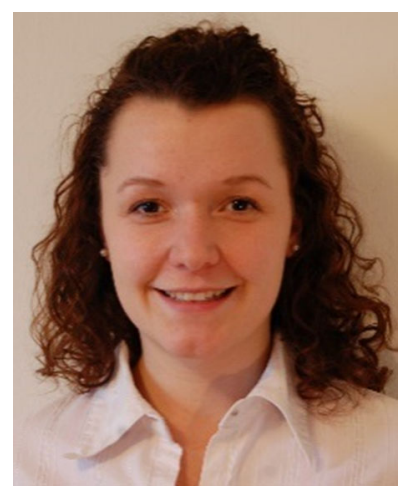

Roswitha Samek $B S c$ serves as research assistant on flood risk management strategies at the Institute of Water Management, Hydrology and Hydraulic Engineering, University of Natural Resources and Life Sciences, Vienna. She holds a diploma in Landscape Architecture and Planning and continued her master's studies in Natural Risk Engineering, where she finishes in 2016. 